ISSN 0258-7122

Bangladesh J. Agril. Res. 36(4): 657-668, December 2011

\title{
THE CHANGING CROP PRODUCTION PRACTICES OVER THE YEARS: THE MYSTERY OF ECONOMICS
}

\author{
M. SHAHE ALAM ${ }^{1}$, M. A. QUAYUM ${ }^{2}$ AND M. A. ISLAM ${ }^{3}$
}

\begin{abstract}
The present study was undertaken in two production environments in order to estimate the level of growth in area and production of rice and maize over the years, and to assess the level of changes in area under different crops. Applying both descriptive and inferential statistics, the study revealed that, the growth in acreage and production of maize had much accelerated rate compared to that for rice over the period 1987-88 towards 1996-97 and in the subsequent periods. In the favourable environment, the acreage under MV Boro increased by $18 \%$ in 2008-09 compared to 2004-05. In rabi season, the area under maize increased to $46 \%$ and $21 \%$ in drought prone and favourable areas, respectively. The magnitude of area changes from rice to non-rice crops under favourable area was negative. Per hectare cost of maize cultivation in drought prone area was about $13 \%$ higher than that of favourable area resulting in better net return in maize production under favourable area. Family labour, farm size and market accessibility were the important determining factors for devoting areas to maize cultivation instead of rice.
\end{abstract}

Keywords: Growth rate, production environment, drought prone, non-rice crops and favourable area.

\section{Introduction}

Bangladesh has been able to make remarkable progress in achieving selfsufficiency in food production through adoption of modern crop varieties in spite of the declining trend in arable land. Due to the scarcity of arable lands, the possibility of horizontal expansion of the net cropped area is almost impossible. Therefore, farmers normally try to optimize their farm output/return through best use of their limited land resource base. Rice being the major food staple, its production is vital to the Bangladesh economy. More than three-fourth of the country's cropped area is devoted for rice cultivation and about $60 \%$ of the total labour force is engaged in rice production (BBS, 2008). Rice alone shares about $95 \%$ of the total cereal food supply. Furthermore, rice alone contributes about 9.5 percent of the total agricultural GDP in the country. Among all crops, rice is the driving force of Bangladesh agriculture. In the recent years, it is well recognized that shifting of crop lands from rice to non-rice crops has been taking place.

However, maize is one of the most important cereal crops and it is one of the leading crops in the world after rice and wheat. Among the food grain crops,

${ }^{1}$ Chief Scientific Officer, Senior Scientific Officer and Scientific Officer, Agricultural Economics Division, BRRI, Gazipur-1701. 
globally maize occupies third position in terms of area and production (Khan, 2003). Maize accounts for $18 \%$ of the world cereal area and about $25 \%$ of the production (Mohiuddin, 2003). Maize as a food crop differs from rice and wheat having a few advantages compared to rice and wheat. The most important one is its diversified uses in different forms, such as food, feed, fodder, industrial use, and fuel, etc. In Bangladesh, the area under maize cultivation during 2004-05 was about 67 thousand hectares and the volume of production was 356 thousand metric tons with an average yield of 5.32 tons per hectare (BBS, 2008). During the last few years, Bangladesh Agricultural Research Institute (BARI) had been able to release as many as 11 high yielding varieties of maize with yielding ability of 8-10 t/ha (Alam, 2009; Matin et al, 2007). It has been recognized that due to rapid diffusion of the newly developed maize varieties, its adoption at farm level has also been expanded. The available statistics also support this consensus (BBS, 2007).

However, it is very much necessary to understand the overall trend in the rate of growth in area and production of both rice and maize over the years. At the same breath, it is important to dig out the farmers' reasons of changing areas from rice to non-rice crops. The findings of this sort of study would be immensely useful to the researchers, policy makers, and also to the research managers. However, taking into considerations of all these issues, the present study was undertaken with the following objectives:

- to estimate the level of growth in area and production of rice and maize over the years;

- to asses the level of changes in area under different crops over the years in some selected areas of Bangladesh;

- to determine the profitability differences in producing maize in the selected production environments; and

- to examine the relative contribution of different factors influencing area devotion to maize cultivation in the selected areas of Bangladesh.

\section{Methodology}

Both primary and secondary data were used in this study. As such, sample survey was carried out in four districts in order to capture two production environments, i.e. favourable and drought-prone environments. Two districts under each environment were selected purposively. Categorically, Bogra and Dinajpur were taken under favourable situation, while Chapai-Nawabgonj and Chuadanga were selected under drought-prone environment. One Upazila from each district and two villages under each Upazila were selected purposively. From a 
comprehensive list of maize growers in each village, twenty farms were selected randomly. Finally, a total of 160 farms were selected for carrying out the sample survey from which the required primary data were generated through using structured questionnaire. The survey was carried out during both rabi and kharif seasons of 2009. The required secondary data were collected from different sources, such as BBS, DAE, and IMMP (Integrated Maize Management Program). Both descriptive and inferential statistics were employed in analyzing the generated data. In the process, however, two regression models were employed:

i) In order to estimate the growth rates, the following exponential growth function was used:

$$
\mathrm{Y}=\alpha \mathrm{e}^{\mathrm{rt}}
$$

Taking logarithm in both sides:

$$
\begin{aligned}
\ln \mathrm{Y} & =\ln \alpha+\ln \mathrm{e} . \mathrm{rt} \\
& =\ln \alpha+\mathrm{rt} \quad[\text { since } \ln \mathrm{e}=1] \\
& =\beta_{1}+\mathrm{rt} \quad\left[\ln \alpha=\beta_{1}\right] \\
& =\beta_{1}+\beta_{2} \mathrm{t} \quad\left[\mathrm{r}=\beta_{2}\right]
\end{aligned}
$$

where, $\mathrm{Y}=$ dependent variable, i.e., area, production etc.

$$
\begin{aligned}
& \text { In }=\text { Natural logarithm } \\
& \mathrm{t}=\text { independent variable/serial time } \\
& \beta_{1}=\text { Intercept } \\
& \beta_{2}=\text { regression coefficient, ( i.e., growth rate) }
\end{aligned}
$$

ii) In order to assess the relative contribution of different biophysical and socioeconomic factors influencing the area devotion to maize production at farm level, a multiple regression model of the following form was employed (Draper and Smith, 1966):

$$
Y_{i}=\beta_{0}+\underset{i=1}{\mathrm{k}} \Sigma \beta_{i} X_{i j}+e_{j}
$$

where; $Y_{j}=$ proportion of area devoted for maize cultivation (i.e. $\%$ of cropped area under maize/farm).

$\mathrm{X}_{\mathrm{i}}$ are the independent/explanatory variables,

$\mathrm{i}=1 \ldots \ldots \ldots \ldots . . . \mathrm{k}$, (i.e. number of independent variables),

$\mathrm{j}=1$.........n, i.e, number of observations, 
$\beta_{i}=$ are the regression coefficients

$\beta_{0}=$ intercept

$\mathrm{e}=$ error term

\section{Results and Discussions}

\subsection{Trend in growth of area, production and yield of rice and maize}

The growth rates of area, production, and yield of rice and maize for the period 1987-88 towards 2006-07 have been presented in Table 1. In estimating the growth trend, the whole period was divided into four sub-periods. In the first period (1987-92), although the growth in rice area had an increasing trend (positive), but it was very negligible; while in the same period, the rate of growth in maize area had a substantial increasing trend. In the second period (1997$2001)$, the growth in rice area had negative trend, while area under maize increased very sharply $(22 \%)$. It is worth mentioning that in the third period (2002-2008), although rice area had declining trend, area under maize had increased very sharply.

Table 1. Trend in growth in area, production, and yield of rice and maize in Bangladesh over the years, 1987-2008.

\begin{tabular}{|c|c|c|}
\hline \multirow[t]{3}{*}{ Period } & \multicolumn{2}{|c|}{ Growth trend $(\%)$} \\
\hline & Rice & Maize \\
\hline & \multicolumn{2}{|c|}{ Area } \\
\hline 1987/88-1991/92 & 0.05 & 2.39 \\
\hline 1992/93-1996/97 & -0.13 & 22.95 \\
\hline $1997 / 98-2001 / 02$ & 1.41 & -8.58 \\
\hline \multirow[t]{2}{*}{$2002 / 03-2007 / 08$} & -0.63 & 33.76 \\
\hline & \multicolumn{2}{|c|}{ Production } \\
\hline 1987/88-1991/92 & 4.73 & 0.39 \\
\hline 1992/93-1996/97 & 0.38 & 42.78 \\
\hline 1997/98-2001/02 & 7.38 & -20.89 \\
\hline \multirow[t]{2}{*}{$2002 / 03-2007 / 08$} & 1.75 & 48.58 \\
\hline & \multicolumn{2}{|c|}{ Yield } \\
\hline 1987/88-1991/92 & 4.73 & -2.02 \\
\hline 1992/93-1996/97 & 0.60 & 19.83 \\
\hline $1997 / 98-2001 / 02$ & 5.92 & -13.17 \\
\hline $2002 / 03-2007 / 08$ & 2.36 & 14.81 \\
\hline
\end{tabular}

Source: BBS, 2008

Although the average rate of production of rice during 1987-1992 was higher (4.7\%), it declined sharply in the next period (1992-97). On the contrary, the rate of maize production was only $0.49 \%$ in the earlier period and there has been a 
severe increasing trend (42.7\%) in the following period (1992-97). However, the rate of production in case of rice during the last period has an increasing trend but with low growth rate $(1.7 \%)$, while the rate of maize production in the same period showed a sharp increasing trend $(48 \%)$.

At the same breath, the rate of growth in rice yield although has gone down from $4.73 \%$ in the first period to $0.60 \%$ in $1992-97$, it has increased to $5.92 \%$ in the next period. Surprisingly, the rate of growth in maize yield has increased from $-2.02 \%$ in the first period to $19.83 \%$ in the second period. Most probably due to the severe flood of 1998, the rate of growth in maize yield in 1998-2002 had a declining trend, However, the growth in maize yield in the last period had an impressive rate of $14.8 \%$.

\subsection{Shifting of area under different crops in Boro and Aus seasons}

The level of area shifting under different crops in Boro season at farmers' level is shown in Table 2. The average area under MV Boro rice has increased by 7 and $11 \%$ in drought prone and favourable area respectively in the year 2008-09 compared to 2003-04. The other important crops for which the changes in acreage was observed were potato, maize, mustard, ground nut, lentil, onion, garlic etc. The area under sugarcane has increased in favourable area while it has decreased in drought prone area.

Table 2. Magnitude of area changes in different crops in Boro season (from 2003-04 to 2008-09).

\begin{tabular}{c|c|c}
\hline Crops & $\begin{array}{c}\text { Drought prone area } \\
\text { area changed (\%) }\end{array}$ & $\begin{array}{c}\text { Favourable } \\
\text { area changed (\%) }\}\end{array}$ \\
\hline MV Boro & 7.05 & 10.82 \\
Potato & 4.31 & 0.31 \\
Maize & 45.56 & 21.20 \\
Mustard & 12.05 & 126.41 \\
Wheat & -12.90 & -28.13 \\
Pepper & -8.33 & -11.49 \\
Vegetables & 6.30 & -51.40 \\
Mug & -50.00 & -0.18 \\
Kalai & -17.65 & -20.30 \\
Tobacco & -79.77 & -11.23 \\
Groundnut & -4.17 & 50.00 \\
Zinger & -20.00 & 5.00 \\
Sugarcane & -21.30 & 113.69 \\
Lentil & 28.57 & -6.66 \\
Onion & 35.00 & 6.25 \\
Garlic & -0.99 & 22.00 \\
\hline
\end{tabular}

Source: Field survey, 2009 
The magnitude of area shifting under different crops in Aus season can be viewed in Table 3. The area under total Aus rice has increased by 27 and 9 percent respectively, in drought prone and favourable area in the year 2008-09 compared to 2003-04. On the other hand the area under MV Aus has increased by $30 \%$ in drought prone area, while in the favourable area, the level of increase was a bit less $(10 \%$ only). The area other increase of the crops like maize, vegetables and pepper have also increased. However, the area of jute, sweet gourd and sesame (til) has decreased at a lesser proportion (Table 3).

Table 3. Magnitude of area changes in different crops in Aus season (from 2003-04 to 2008-09).

\begin{tabular}{c|c|c}
\hline Crops & $\begin{array}{c}\text { Drought prone area } \\
\text { area changed }(\%)\}\end{array}$ & $\begin{array}{c}\text { Favorable } \\
\text { area changed }(\%)\}\end{array}$ \\
\hline MV Aus & 29.72 & 10.02 \\
LV Aus & -20.00 & -0.88 \\
Total & 26.64 & 9.12 \\
Jute & -81.50 & -18.42 \\
Maize & 211.85 & 33.65 \\
S.gourd & -3.92 & - \\
Ground nut & 42.00 & -14.29 \\
Vegetables & 7.50 & 18.50 \\
Pepper & 25.00 & 21.74 \\
Til & -6.00 & -2.30 \\
\hline
\end{tabular}

Source: Field survey, 2009

\subsection{Inputs used for maize cultivation}

Per hectare input used for maize cultivation is shown in Table 4. The average seed rate of maize was found $23 \mathrm{~kg} / \mathrm{ha}$, in drought prone area and $21 \mathrm{~kg} / \mathrm{ha}$ in favorable area. The average rate of urea, TSP and MP were 357, 190 and 86 $\mathrm{kg} / \mathrm{ha}$. Farmers in both drought prone area and favorable area used manure at the rate of 3580 and $4320 \mathrm{~kg} / \mathrm{ha}$ respectively. The human labor requirement was found higher in drought prone area (199 man day/ha) compared to favorable area (163 manday/ha). 
Table 4. Per hectare input used for Maize cultivation in some selected areas of Bangladesh.

\begin{tabular}{|c|c|c|c|}
\hline Inputs used & Drought prone & Favourable & Average \\
\hline Seeds (kg/ha): & 23 & 21 & 22 \\
\hline Owned & - & - & - \\
\hline Purchased & 23 & 21 & 22 \\
\hline \multicolumn{4}{|l|}{ Fertilizer (kg/ha): } \\
\hline Urea & 352 & 362 & 357 \\
\hline TSP & 240 & 140 & 190 \\
\hline MP & 93 & 78 & 86 \\
\hline Gypsum & 14 & 16 & 15 \\
\hline SSP/DAP & - & - & - \\
\hline Znso4 & 8 & 6 & 7 \\
\hline Manure & 3580 & 4320 & 3950 \\
\hline \multicolumn{4}{|c|}{ Labor (mandays/ha): } \\
\hline Family & 121 & 102 & 112 \\
\hline Hired & 78 & 61 & 70 \\
\hline \multicolumn{4}{|c|}{ Bullock power (hr/ha): } \\
\hline Family & 6.5 & 5.5 & 6 \\
\hline Hired & - & - & - \\
\hline \multicolumn{4}{|l|}{ Power tiller (hr/ha): } \\
\hline Family & - & - & - \\
\hline Hired & 27 & 23 & 25 \\
\hline
\end{tabular}

Source: Field survey, 2009

\subsection{Comparative cost analysis}

The cost of human labour in drought prone area was found higher (Tk. 29621/ha) than that of favourable areas (Tk. 23741/ha) and the average cost of it was Tk. 26682/ha (Table 5). The average land preparation cost was Tk. 5297/ha. The cost of seed and fertilizer was Tk. 4568/ha and Tk. 14850/ha, respectively. The irrigation cost was found higher in drought prone area compared to favourable area. The total cost of maize cultivation in drought prone area and favourable area was Tk. 75859/ha and Tk. 66424/ha and the average of it was Tk. 71143 per hectare. 
Table 5. Cost of maize cultivation (Tk./ha) in some selected areas of Bangladesh.

\begin{tabular}{l|c|c|c}
\hline \multicolumn{1}{c|}{ Items used } & Drought prone & Favourable & Average \\
\hline Total human labor: & 29621 & 23741 & 26682 \\
$\quad$ Family & 18176 & 14911 & 16545 \\
$\quad$ Hired & 11443 & 8831 & 10137 \\
Bullock power: & & & \\
$\quad$ Family & 1017 & 968 & 993 \\
$\quad$ Hired & - & - & - \\
Power tiller: & & & \\
$\quad$ Family & - & - & - \\
$\quad$ Hired & 4382 & 4225 & 4304 \\
Seeds: & & & \\
$\quad$ Owned & - & - & - \\
$\quad$ Purchased & 4766 & 4369 & 4568 \\
Fertilizer: & & & \\
$\quad$ Inorganic & 16200 & 13500 & 14850 \\
$\quad$ Organic & 2920 & 3370 & 3145 \\
Insecticides & 1500 & 1400 & 1450 \\
Irrigation & 4800 & 4230 & 4505 \\
Interest @10\% for 4 months & 1087 & 930 & 1008 \\
Land rent & 9566 & 9691 & 9628 \\
Total & 75859 & 66424 & 71143 \\
\hline
\end{tabular}

Source: Field survey, 2009

\subsection{Profitability in maize cultivation}

The average yield of maize was found higher in favourable area compared to drought prone area (Table 6). The average yield of maize was $7760 \mathrm{~kg} / \mathrm{ha}$ in favourable area. The gross return, net return, and benefit cost ratio were found higher in favourable area compared to drought prone area. The average gross return, net return, and BCR were Tk. 84800/ha, Tk. 13657/ha, and 1.19, respectively in favourable area on full cost basis.

\subsection{Factors influencing area devotion to maize}

Linear regression function was estimated in order to assess the influence of different bio-physical and socio economic factors on area devotion to maize using the following empirical specification: 
$\mathrm{Y}=\mathrm{a}+\beta_{1}$ farm $+\beta_{2}$ famil. labor $+\beta_{3}$ Irrigation $+\beta_{4}+$ Income $+\beta_{5}$ educ $+\beta_{6} \mathrm{Mkt}$ access $+D_{1}$ Tenancy $+D_{2}$ land type $+e_{i}$.

Where,

$$
\begin{array}{ll}
\mathrm{Y} & =\text { area devoted to maize (in acre/farm) } \\
\text { farm } & =\text { farm size in acre } \\
\text { Fami. lab } & =\text { Number of Agril. labour/farm } \\
\text { Irrigation } & =\% \text { area under irrigation } \\
\text { Educ } & =\text { Education of the operation (schooling year) } \\
\text { Mkt access } & =\text { Accessibility to market (distance in } \mathrm{km}) \\
\text { Income } & =\text { Household annual income }(\mathrm{Tk} . / \mathrm{HH}) \\
\text { Tenancy } & =\text { Tenancy dummy (taking own plot }=1, \text { otherwise } 0) \\
\text { Land type } & =\text { Land type dummy (medium land }=1 \text {, otherwise } 0) \\
\mathrm{e} & =\text { error term }
\end{array}
$$

Table 6. Average cost and returns (Tk./ha) of maize cultivation at some selected areas of Bangladesh.

\begin{tabular}{lcccc}
\hline \multicolumn{1}{c|}{ Items used } & Drought prone & Favourable & Average \\
\hline Yield (kg/ha): & 7310 & 7760 & 7535 \\
Gross return (Tk/ha) & 81495 & 88104 & 84800 \\
Total cost (Tk/ha): & & & \\
\multicolumn{1}{c}{ Full cost basis } & 75859 & 66424 & 71143 \\
Cash cost basis & 46011 & 39925 & 42969 \\
Net return (Tk/ha): & & & \\
Full cost basis & 5636 & 21680 & 13657 \\
Cash cost basis & 35484 & 48179 & 41831 \\
Benefit-cost ratio: & & & 1.19 \\
Full cost basis & 1.07 & 1.33 & 1.97 \\
Cash cost basis & 1.77 & 2.21 & \\
\hline
\end{tabular}

Source: Field survey, 2009 
Table 7. Estimates of linear regression function on factors influencing area devotion to maize in the study areas.

\begin{tabular}{|c|c|c|}
\hline Independent variables & Reg. coefficients & $\mathrm{t}$-statistics \\
\hline Intercept & 0.823 & 0.641 \\
\hline $\mathrm{X}_{1}=$ Farm size $(\mathrm{ha})$ & $0.023^{* *}$ & 2.861 \\
\hline $\mathrm{X}_{2}=$ Family agril. labour & $0.201^{* *}$ & 3.582 \\
\hline $\mathrm{X}_{3}=$ Area under irrigation (\% area) & 0.187 & 1.1951 \\
\hline $\mathrm{X}_{4}=$ Total income & -0.0325 & -0.015 \\
\hline $\begin{aligned} X_{5}= & \text { Farmers' education } \\
& \text { (years of schooling) }\end{aligned}$ & 0.031 & 1.727 \\
\hline $\begin{array}{c}\mathrm{X}_{6}=\text { Tenancy dummy ( owner operator } \\
=1 \text { ) }\end{array}$ & 0.204 & 1.062 \\
\hline $\begin{aligned} \mathrm{X}_{7}= & \text { Soil type dummy } \\
& \quad(\text { loamy }=1, \text { otherwise } 0)\end{aligned}$ & -0.0637 & -1.023 \\
\hline $\begin{array}{l}\mathrm{X}_{8}=\text { Land type dummy } \\
\quad(\text { Medium land }=1, \text { otherwise } 0)\end{array}$ & $0.0922 *$ & 2.250 \\
\hline $\mathrm{X}_{9}=$ Market accessibility & $0.0218 * *$ & 2.591 \\
\hline F-value & $23.709 * * *$ & 4.518 \\
\hline $\mathrm{R}^{2}$ & \multicolumn{2}{|c|}{0.610} \\
\hline
\end{tabular}

$*$, ** and $* * *$ means significant at $10 \%, 5 \%$, and $1 \%$ probability levels, respectively.

Source: Field survey, 2009

Estimated results of the above (OLS) regression function are presented in Table 7. The $\mathrm{R}^{2}$ of the estimated function appear to be moderate. The coefficients of most of the explanatory variables had the expected signs except one. Among all independent variables, farm size, family labour, market accessibility were found to be significantly influencing factors for farmers' area devotion to maize cultivation.

Farm size was positive and significant implying that the larger is the farm size, higher will be the area devotion to maize. Similarly, the coefficient of family agril. worker was positive and statistically significant implying that availability of own agril. worker would encourage farms to devote more land for maize cultivation. On the other hand, the coefficient for the variable market access was negative and significant indicating that with an increase in market distance, the sample farms tended to devote less land for maize cultivation. However, land type refers to the medium land dummy. The coefficient for land type was positive and significant implying that maize acreage increased with the availability of medium land not with high land or low land type. This result is in consonance with some earlier study (Saha et al., 2001; Alam et al., 2008). 


\section{Conclusion}

From the present study, the following conclusions were drawn: The growth in both area and production of maize over the period 1992-2008 increased at a much higher rate compared to that of rice implying that maize cultivation has been getting popularity among the farming community probably due to higher profitability in maize production. This study also revealed that area under wheat decreased due to high cost of cultivation and low yield, but maize areas increased both in drought prone and favourable areas. Area under some non-rice crops (e.g., potato, tomato, vegetable, etc.) increased since producers could derive better economic margin from growing those crops. Requirement of human labour for maize production was $22 \%$ higher in drought prone areas compared to that of favourable areas. Per hectare cost of human labour in drought prone area was also higher (about 25\%) compared to favourable area. Although irrigation cost for maize was higher in the drought prone area, it was higher for rice in the favourable area since more intensive rice cropping was practiced in the favourable area. Farmers in the favourable area obtained higher maize yield than their counterparts in the drought prone area. The gross return, net return, and benefit cost ratio were higher in favourable area compared to drought prone area. Production of maize was more profitable than rice (on cash cost basis) both in drought prone and favourable areas. The study showed that farm size, family agricultural worker, and access to market were the prominent determinants in area devotion in maize cultivation in the study areas. Maize cultivation may be encouraged since more economic returns could be accrued from growing this crop.

\section{References}

Alam M.S. 2009. BARI Contribution to Food Security in Bangladesh. Paper presented in the 21st Bangladesh Science Conference, Bangladesh Association for the Advancement of Science, Bangladesh Agricultural Research Institute, Gazipur, 1820 February.

Alam M. Shahe and M.A. Quayum.2008. Shifting from rice to non-rice crop production in Bangladesh: An analysis of farmers' view. The Agriculturists, Vol. 6(1\&2), pp. 124-131.

Bangladesh Bureau of Statistics BBS. 2007. 2008. Statistical Year Book of Bangladesh, Statistics Division, Ministry of Planning, Government of the People's Republic of Bangladesh, Dhaka.

Draper, N. R., and H. Smith. 1966. Applied Regression Analysis, John Wiley and Sons Inc, New York.

Khan, M.R. 2003. Role of agrobased industry for national economic development. Key note paper presented in the Seminar on 'Role of Agrobased Industry for National Economic Development'. Organized by Agriculturists' Forum of Bangladesh. Bangladesh Agricultural Research Council, Dhaka, July, 24. 
Matin, M. A, M. S. Rahman, M. R. Karim and M. I. Hossain 2007. Maize marketing system in selected areas of Bangladesh. Bangladesh Journal of Agriculture Vol. XXXII (I).

Mohiuddin, M. 2003. Efficiency and Sustainability of Maize Cultivation in an Area of Bangladesh, Unpublished M.S. Thesis, Submitted to the Department of Agricultural Economics, Bangladesh Agricultural University, Mymensingh.

Saha, R. R., M. S. Rahman and P. C. Golder. 2001. Maize - lentil, Intercropping and effect of detopping of maize after silking. Bangladesh Journal of Agricultural Research Vol. 26 (III). 